\title{
Temperature Influence Bacterial Residual of Escherichia Coli Associated with Lettuce
}

\author{
Zhang Tongwei \\ Food Science and Engineering College \\ Beijing University of Agriculture \\ Beijing, China \\ e-mail: zhangtongwei-windy@163.com
}

\author{
Tan Feng*, Hou Maoshu, Dong Xiang \\ International College, Beijing University of Agriculture \\ Beijing, China \\ e-mail:\{tanfeng, houmaoshu, dongxiang\}@bua.edu.cn \\ *Corresponding author
}

\author{
James M. Monaghan \\ Harper Adams University \\ Newport, UK \\ e-mail: jmonaghan@harper-adams.ac.uk
}

\begin{abstract}
Bacterial contamination is one of the most concern for food safety control in supply chain of fresh vegetables. The bacterial residual is available to be used for expression of the potential risk. Select Escherichia coli 1.1187 as a target to simulate bacterial contamination associated with lettuce. By meant of detection in front and afterwards of clean with citric acid solution and sterile water, it is measured the bacterial growth and residual within 70 hrs cultures at different temperature. The results show that temperature plays positive impact with the population and rate of bacterial residual significantly. The bacterial residual rate at $4^{\circ} \mathrm{C}, 10^{\circ} \mathrm{C}, 24^{\circ} \mathrm{C}$ and $37^{\circ} \mathrm{C}$ reach $11.9 \%, 15.8 \%, 18.8 \%$ and $22.1 \%$ respectively; and the accumulated residual rate reach $6.1 \%, 17.6 \%, 89.4 \%$ and $125.8 \%$ respectively.
\end{abstract}

Keywords-escherichia coli; lettuce; temperature; residual

\section{INTRODUCTION}

For vegetables, especially the ready-to-eat vegetable cooking such as lettuce, microbiological contamination is the most critical safety issue to consumers. Vegetables infected by food borne pathogenic microorganisms not only drop down food quality, but also pose a threat to the health of consumers. Currently the number of food borne diseases increased year by year related with lettuce and presented a great potential risk [1-3].

Bacteria can usually grow on the surface of fruits and vegetables, but with the environmental conditions change, the colony types may also get changed, leading to the growth of pathogenic bacteria and resulting in varied level of hazard to eaters [4].

There were a mount of studies focused on the methods of cleaning and disinfecting in order to decrease the potential risk of microbial contamination associated with fresh vegetables. Two steps washing with chemicals and potable water are generally involved in such clean section [5, 6]. It is one of the key factors for fresh lettuce to maintain the food quality by applying cold chain as it is hardly to remove all microbes from vegetables through any current methods of cleaning and disinfection. Lower temperature can effectively inhibit the growth of microorganisms and help reduce the intensity of cellular respiration and the speed of browning, as well as speed of physiological and biochemical reaction. [7].

Many researches were conducted to discover the pathways of microbial contamination and the ways of cleaning and disinfecting [8-12], but there would be little studies on related factors influence bacterial residual associated with fresh vegetables through supply chain. The bacterial residue may be due to the process of the attachment and internalization between bacteria and vegetables since the microbial contamination occurred [13, 14]. This paper is tried to understand how temperature influence the bacterial residue within a period of contamination. Escherichia coli 1.1187, a class branch of Escherichia coli K12, was used as an alternative of pathogenic Escherichia coli in this experiment [15-17].

\section{Materials AND Methods}

\section{A. Materials}

Iceberg lettuce purchased from the northern suburb market in Beijing; Escherichia coli 1.1187 purchased from the Institute of Microbiology of the Chinese Academy of Sciences; Nalidixic acid purchased from Beijing Lanyi Chemical Co., Ltd.; Nutrient agar purchased from Beijing Land Bridge Technology Co., Ltd.

\section{B. Research Methods}

1) Sample and bacterial suspension preparation

Preparation of the bacterial suspension: Escherichia coli 1.1187 crossed subculture on nutrient agar medium for 24h at $37^{\circ} \mathrm{C}$, pick single colony into a conical flask containing $100 \mathrm{~mL}$ saline and shake well.

Preparation of the samples: select fresh lettuce and remove the two or three surface layers, take a piece of washed leaf weighting in $25 \mathrm{~g}$ and pack into sterile plastic bags. 
Inoculate: Suck up bacterial suspension in accordance with the proportion of $1 \mathrm{~mL} / 100 \mathrm{~g}$ to inoculate on the leaves of lettuce, place in required temperature and stable for $15 \mathrm{~min}$.

\section{2) Bacterial culture and detection}

Bacterial culture: put the sample bags to be cultured at $4^{\circ} \mathrm{C}, 10^{\circ} \mathrm{C}, 24^{\circ} \mathrm{C}$ and $37^{\circ} \mathrm{C}$ respectively and measure bacterial counts at pointed times in front and afterwards of clean treatment to sample leaves.

Clean method: soak sample leaves into 150mg/L citric acid solution for $3 \mathrm{~min}$, and then rinse with sterile water for 3min.

Detection of Escherichia coli: add 225mL saline into a sample bag and beat the bag 1-2min to make 1:10 uniform liquid. Dilute the uniform liquid, select the appropriate concentration, and draw $1 \mathrm{~mL}$ dilution mixed with $15-20 \mathrm{~mL}$ selective media of nutrient agar joined by nalidixic acid. Check the total number of bacteria after $48 \mathrm{~h}$ at $37^{\circ} \mathrm{C}$. Referencing the method of National food safety standard GB 4789.2-2010 《 Food microbiological examination: Aerobic plate count $》$, count the colony of dilution in $1 \mathrm{CFU} / \mathrm{g}$.

3) Residual rate and data analysis

Residual rate: percentage of remained bacterial counts in cleaned sample from total counts in the samples without cleaning.

Accumulated residual rate: percentage of remained bacterial counts in cleaned sample from initial population of bacterial contamination.

Data analysis: the data are analyzed and plotted by Origin 6.0 software.

\section{Results AND ANALYSIS}

\section{A. Trends of Escherichia coli growth and residual on lettuce at different temperature}

Introduced Escherichia coli onto the leaves of lettuce and cultured at $4^{\circ} \mathrm{C}, 10^{\circ} \mathrm{C}, 24^{\circ} \mathrm{C}$, and $37^{\circ} \mathrm{C}$ respectively. Measured the bacteria counts of Escherichia coli growth and residual during the incubations. The results are expressed in Figure 1 and 2 respectively.



Figure 1. Population of E. coli growth and residual at normal temperature

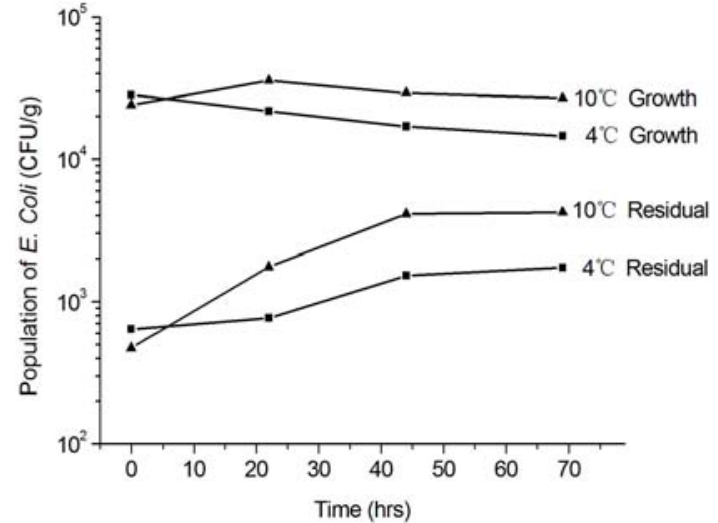

Figure 2. Population of E. coli growth and residual at cold temperature

From Figure 1, it is indicated that both Escherichia coli populations of growth and residual are increased in normal temperatures, and the residual presents more intensive than growth. From Figure 2, it is observed that Escherichia coli growth can be inhibited effectively by the low temperatures, but the residual gets increased correspondingly. Both picture present that a higher temperature leads a more bacterial residual of Escherichia coli existing with lettuce.

\section{B. Bacterial residual rate of Escherichia coli on lettuce at different temperature}

Bacterial residual rate is used to introduce the intension of bacteria attached to vegetable that expressed by the percentage of remained population from untreated sample. It indicates the strength of bacteria attachment and Internalization with green leaves. By calculating the bacterial residual rate of Escherichia coli at $4^{\circ} \mathrm{C}, 10^{\circ} \mathrm{C}, 24^{\circ} \mathrm{C}$, and $37^{\circ} \mathrm{C}$ for $70 \mathrm{hrs}$, the results reached $11.9 \%, 15.8 \%, 18.8 \%$ and $22.1 \%$ respectively.

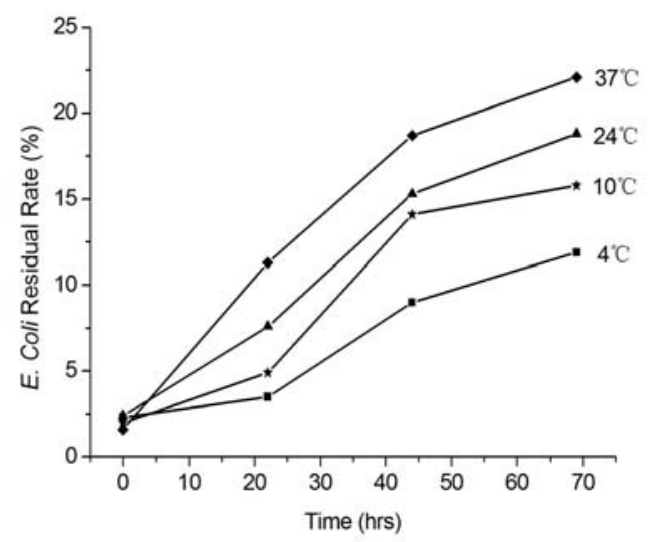

Figure 3. Residual rate of $E$. coli on lettuce at different temperature

From Figure 3, it can be seen that temperature plays a positive impact with the bacterial residual rate. That is, a higher temperature will lead a more population of Escherichia coli to be attached on lettuce leaves that 
presented more difficult to be cleaned. It surmised the reason that may be due to the growth area for Escherichia coli is expanding. It is also possible that those Escherichia coli forming bio-films during theirs growth and get enhancing of their adhesion ability and protecting from washing and cleaning. Overall, with the extension of time and the increase of temperature, the adhesion ability of the Escherichia coli on lettuce is enhanced.

\section{Accumulate bacterial residual rate of Escherichia coli on lettuce at different temperature}

Accumulate bacterial residual rate refers to the vegetable was contaminated by bacteria after a certain time, the percentage of bacterial residual from the initial population of the contamination. By calculating the accumulated bacterial residual rate of Escherichia coli at $4^{\circ} \mathrm{C}, 10^{\circ} \mathrm{C}, 24^{\circ} \mathrm{C}$, and $37^{\circ} \mathrm{C}$ for $70 \mathrm{hrs}$, the results reached $6.1 \%, 17.6 \%, 89.4 \%$ and $125.8 \%$ respectively.

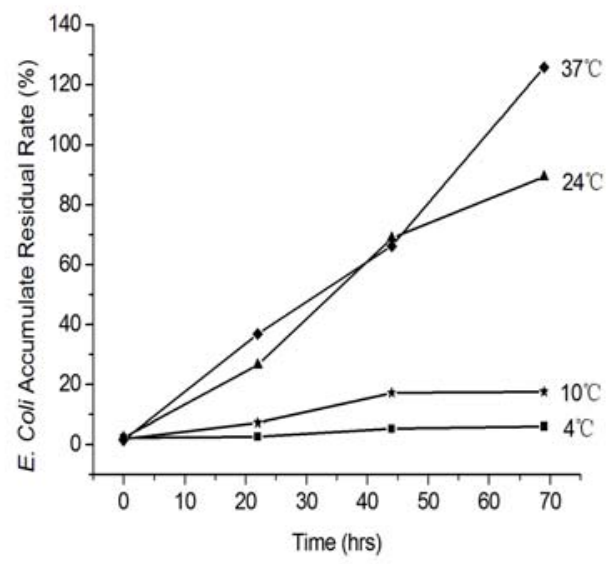

Figure 4. Accumulate residual rate of E. coli on lettuce at different temperature

As can be seen from Figure 4, lower temperatures lead lower accumulate rate of bacterial residual relatively and display a limited increase from the initials. But in higher temperatures, the accumulate rate of bacterial residual gets increased faster with a similar type of linear. The accumulate rate of bacterial residual at $37^{\circ} \mathrm{C}$ even more than double of the initial amount of the contamination. Accumulate rate of bacterial residual is different from bacterial residual rate, because the latter is a current record with a mutative cardinality. The bacterial residue may be due to the attachment and internalization between bacteria and vegetables after microbial contamination occurred.

\section{Discussion}

The concept of bacterial contamination and residual are different, the previous studies were generally focused on the bacterial contamination with vegetables. It is rarely to be found to study about bacterial residues. However, residue is more closely to food safety. Proposed two conceptions of bacterial residual rate and accumulate bacterial residual rate play important roles in food safety management.
Within the whole supply chain of vegetables, it is produced a numbers of opportunities for bacterial contamination such as planting, harvesting, transporting, processing, storing, and retailing. The lettuce in planting and harvesting stage will be not carried with cleaning treatment until gets into the processing segment. If bacterial contamination occurred in planting or harvesting stage, it would be likely to lead a further growth and reproduction of bacteria on the surface of lettuce. With the extension of time, the population of the remained bacteria also gets increased and leads more potential risk with the food safety.

The analysis results of the study can help us look the key control points in lettuce supply chain and take reasonable measures for prevention. We should strengthen planting and other aspects of management, make strictly control with soil, water and fertilizers and ensure cleaning of personnel and tackle in processing sectors. The bacterial growth can be inhibited effectively by the low temperatures, so we can as far as possible ensure that the entire supply chain at a low temperature conditions. Try to avoid mechanical damage of lettuce in the supply chain can also help reduce the risk of microbial infestation, extend shelf life and ensure the safety of lettuce.

\section{ACKNOWLEDGMENT}

Appreciate Beijing University of Agriculture provide the support and facilities on this research. Thanks to my colleagues Li Xiaowei and Wang Dan for their assistance in the laboratory works.

\section{REFERENCES}

[1] S. Kish, "California Firm Recalls Grilled Chicken Salad Products Due To Possible E.coli O157:H7 Contamination,” Congressional and Public Affairs, 2014.

[2] L. Layton, "Pre-cut lettuce is suspected cause of food poisoning outbreak," The Washington Post, 2010.

[3] M.A.D. Oliveira, "Microbiological quality of ready-to-eat minimally processed vegetables consumed in Brazil,” Food Control, vol. 22(8), pp. 1400-1403, 2011.

[4] W.Q. Guan, Z.L. Jing, and N. Zhang, "Contributing Factors and Control of Bacterial Pathogens in Fresh Fruits and Vegetables During Storage and Transportation," Storage and Process, vol. 8(1), pp. 1-4, 2008.

[5] M.I.Gil, M.V. Selma, and F. López Gálvez, "Fresh-cut product sanitation and wash water disinfection: Problems and solutions," International Journal of Food Microbiology, vol. 134, pp. 37-45, 2009.

[6] H. Ölmez, and U. Kretzschmar, "Potential alternative disinfection methods for organic fresh-cut industry for minimizing water consumption an environmental impact," LWT-Food Science and Technology, vol. 42, pp. 686-693, 2009.

[7] H. Ölmez, and U. Kretzschmar, "Potential alternative disinfection methods for organic fresh-cut industry for minimizing water consumption and environmental impact," Food Science and Technology, vol.42, pp. 686-693, 2009.

[8] M. Selma, A. Allende, F. Lopez Galvez, M. Conesa, and M. Gil, "Disinfection potential of ozone, ultraviolet-C and their combination in wash water for the fresh-cut vegetable industry," Food Microbiology, vol. 25(6), pp. 809-814, 2008.

[9] M. Gil, M. Selma, F. López Gálvez, and A. Allende, "Fresh-cut product sanitation and wash water disinfection: Problems and 
solutions,” International Journal of Food Microbiology, vol. 134(1-2), pp. 37-45, 2009.

[10] A. Allende, M. Selma, F. Lopez Galvez , R. Villaescusa, and M. Gil, "Impact of wash water quality on sensory and microbial quality, including Escherichia coli cross-contamination, of fresh-cut escarole,” Journal of Food Protection, vol. 71(12),pp. 2514-2518, 2008.

[11] S. Hati, S. Mandal, P. Minz, S. Vij, Y. Khetra, and D. Yadav, "Electrolyzed oxidized water (EOW): Non-thermal approach for decontamination of food borne microorganisms in food industry," Food and Nutrition Sciences, vol. 3(6), pp. 760-768, 2012. doi:10.4236/fns.2012.36102 .

[12] X. Nou, and Y. Luo, "Whole-leaf wash improves chlorine efficacy for microbial reduction and prevents pathogen cross-contamination during fresh-cut lettuce processing," Journal of Food Science, vol.75(5), 2010.

[13] S. Pu, J. Beaulieu, W. Prinyawiwatkul, and B. Ge, "Effects of plant maturity and growth media bacterial inoculum level on the surface contamination and internalization of Escherichia coli O157:H7 in growing spinach leaves,” Journal of Food Protection, vol. 72(11), pp. 13-20, 2009.

[14] M. Erickson, C. Webb, L. Davey, A. Payton, I. Flitcroft, and M. Doyle, "Internalization and fate of Escherichia coli O157:H7 in leafy green phyllosphere tissue using various spray conditions,” Journal of Food Protection, vol.77(5), pp. 713-721, 2014.

[15] S. Hooper and O. Berg, "Gene import or deletion: A study of the different genes in Escherichia coli strains K12 and O157:H7,” Journal of Molecular Evolution, vol. 55, pp. 734-744, 2002, doi: 10.1007/s00239-002-2369-2.

[16] J. Baranyi, and T.A. Roberts, "A dynamic approach to predicting bacteria growth in food,” Food Microbial, vol.23, pp. 277-294, 1994.

[17] S. Koseki, and S. Isobe, "Prediction of pathogen growth on iceberg lettuce under real temperature history during distribution from farm to table,” International Journal of Food Microbiology, vol.104, pp. 239248, 2005. 